\title{
Menakar Representasi Dalam Konflik di Pulau Pari Kepulauan Seribu Jakarta
}

\author{
Nadia Nur Fitriana \\ Ilmu Pemerintahan, Fakultas Ilmu Sosial dan Ilmu Politik, Universitas Sultan Ageng Tirtayasa \\ nadianurfitriana26@gmail.com
}

\begin{abstract}
This research discuss about land conflict between actors happen in Pari Island involving society, local government and sovereign conflict happen because there are struggle land ownership namely society and sovereign claim each other ownership right to the land. The conflict gets worse when there are not clarity of local government in respon this problem, even local government tend to support one of them. This research aim for knowing th spread of conflict in Pari Island through representation theory from Hanna F. Pitkin, that are formalistic representation, deskriptif representation, symbolic representation, and subtantantif representation. Research methods using qualitative method with case study approach, as for data used are primary and secondary. The result of this research showing that land conflict in Pari Island consists of two forms namely vertical and horizontal. Power relation which comes from actors are involved in this conflict seen in the perspective representation theory. Namely, the societies leads to symbolic representation and descriptive representation. While local government as formalistic representation and Ombudsman as substantive representation.
\end{abstract}

Keywords: representation, conflict, spread, land dispute

\begin{abstract}
Abstrak
Penelitian ini membahas tentang konflik pertanahan antar aktor yang terjadi di Pulau Pari, yang melibatkan masyarakat, Pemerintah daerah dan Penguasa. Konflik terjadi karena adanya perebutan kepemilikan tanah dimana masyarakat dan penguasa saling mengklaim kepemilikan hak atas tanah tersebut. Konflik semakin parah ketika tidak ada kejelasan Pemerintah Daerah dalam menyikapi permasalahan yang ada, bahkan pemerintah daerah cenderung mendukung salah satu pihak. Penelitian ini bertujuan untuk mengetahui persebaran konflik di Pulau Pari melalui teori representasi dari Hanna.F.Pitkin yang terdiri dari representasi formalistik, deskriptif, simbolik, dan substantif. Metode penelitian yang digunakan adalah metode kualitatif dengan pendekatan studi kasus, adapun data yang digunakan adalah data primer dan sekunder. Hasil penelitian ini menunjukan bahwa konflik pertanahan di Pulau Pari terdiri dari 2 bentuk yakni vertikal dan horizontal. Relasi kuasa yang berasal dari aktor-aktor yang terlibat dalam konflik dilihat dalam sudut
\end{abstract}


pandang teori representasi dimana masyarakat mengarah pada representasi simbolik dan deskrtiptif. Sedangkan pemerintah masuk dalam representasi formalistik dan Ombudsman sebagai representasi Substantif.

Kata Kunci: representasi, konflik, persebaran, sengketa tanah,

\section{Pendahuluan}

Tanah merupakan faktor utama dalam menentukan fase kehidupan, tanah juga berfungsi sebagai sumber kekayaan karena tanah dan kandungannya bisa memberikan berbagai sumber pendapatan bagi pemiliknya ataupun mereka yang menguasai. Dengan melihat begitu pentingnya pemilikan tanah maka tak jarang konflik atau sengketa tanah sering terjadi dari masa ke masa.

Jumlah konflik agraria di indonesia pada tahun 2017 terdapat 659 konflik dengan cakupan 520.491 Ha yang tersebar di provinsi di Indonesia (Konsorsium Pembaruan Agraria). Sedangkan jumlah konflik yang tersebar di Provinsi DKI Jakarta adalah sebagai berikut :

Tabel 1

Jumlah kasus sengketa tanah di Provinsi DKI Jakarta tahun 2017

\begin{tabular}{|l|l|l|l|l|}
\hline No & Kota/ Kab & Jumlah Pengaduan & Jumlah Penyelesaian & Sisa \\
\hline 1. & Jakarta Timur & 61 & 53 & 8 \\
\hline 2. & Jakarta Selatan & 41 & 17 & 24 \\
\hline 3. & Jakarta Barat & 30 & 13 & 17 \\
\hline 4. & Jakarta Utara & 35 & 15 & 20 \\
\hline 5. & Jakarta Pusat & 22 & 20 & 2 \\
\hline & Jumlah & 189 & 118 & 71 \\
\hline
\end{tabular}

Sumber : BPN DKI Jakarta

Berbagai bentuk sengketa tanah di Indonesia sering kali menimbulkan konflik berkepanjangan baik konflik antar individu dengan individu, kelompok dengan kelompok, maupun individu dengan kelompok. Hal ini akan berdampak pada kehidupan masyarakat apalagi jika konflik yang terjadi bukan hanya antara masyarakat dengan penguasa, tetapi juga antara masyarakat dengan masyarakat seperti yang terjadi di Pulau Pari Kepulauan Seribu, Jakarta. Pulau Pari merupakan salah satu pulau di Kepulauan Seribu, Jakarta dan di Pulau Pari terdapat satu objek wisata yang sedang berkembang pesat yakni Pantai Pasir Perawan. Masyarakat Pulau Pari saat ini dulunya adalah warga Pulau Tidung yang bekerja mencari ikan di Pulau Pari, seiring berjalannya waktu, satu per satu dari mereka tinggal di Pulau Pari, karena mereka melihat pulau pari tidak ada yang mengurus dan memelihara padahal sumber daya alam yang ada di pulau pari sangat melimpah seperti rumput laut dan biota laut lainnya yang dapat membantu mereka melangsungkan hidupnya 
(Direktori Pulau Pulau Kecil Indonesia).

Hasil melaut dan budi daya rumput laut semakin hari semakin menurun serta tidak menentu akibat cuaca yang ekstrem. Dari sinilah masyarakat mulai berpikir bagaimana caranya mempertahankan kelangsungan hidup mereka dan kemudian mereka berinisiatif menjadikan pulau pari sebagai objek wisata, salah satunya adalah pantai pasir perawan. Pantai pasir perawan dibuka dan dikelola oleh masyarakat secara swadaya, mereka menyulap pantai dan lahan disekitarnya yang awalnya semak belukar menjadi pantai yang indah. Hal inilah yang membantu masyarakat membangkitkan roda perekonomiannya karena dapat membuka lapangan pekerjaan bagi masyarakat setempat melalui penyewaan home stay, membuka warung-warung kecil dan usaha lainnya. Bahkan hasil yang didapat jauh lebih besar daripada hasil dari melaut dan budi daya rumput laut karena wisatawan yang berkunjung ke Pulau Pari dari tahun ke tahun relatif meningkat. Berikut merupakan jumlah wisatawan di Pulau Pari, Kepulauan Seribu.

Tabel 2

Jumlah Wisatawan Pulau Pari, Kepulauan Seribu

\begin{tabular}{|c|c|}
\hline Tahun & Jumlah Wisatawan \\
\hline 2011 & 9.382 \\
\hline 2012 & 36.238 \\
\hline 2013 & 173.571 \\
\hline 2014 & 476.612 \\
\hline 2015 & 126.008 \\
\hline 2016 & 807.330 \\
\hline
\end{tabular}

Sumber : BPS Kab. Administrasi Kepulauan Seribu

Seiring dengan berkembang pesatnya objek wisata di Pulau Pari dan semakin banyak jumlah wisatawan ternyata ada pihak swasta yang mengklaim bahwa 90\% dari luas pulau pari sekitar 41,32 Ha adalah milik PT.Bumi Pari Asih, dan 10\% adalah milik Lembaga Ilmu Pengetahuan Indonesia (LIPI) karena memang di sebelah utara Pulau Pari terdapat Lembaga Ilmu Pengetahuan Indonesia (LIPI). Dari sinilah konflik antara masyarakat pulau pari dengan PT.Bumi Pari Asih di mulai (Tribun News). PT. Bumi Pari Asih merupakan Perusahaan yang terbentuk dari gabungan beberapa pemilik lahan Pulau Pari yang kemudian bersatu dan berkonsorsium membuat perusahaan untuk membangun resort di Pulau Pari, namun hal itu mendapat perlawanan dari sebagian masyarakat Pulau Pari karena masyarakat menganggap bahwa lahan yang ditempatinya selama ini tak berpenghuni yang kemudian dikembangkan menjadi objek wisata oleh masyarakat sekitar sehingga mereka beranggapan bahwa masyarakat memiliki hak terhadap Pulau Pari (Tribun News).

Hasil wawancara penulis dengan salah satu warga Pulau Pari yang 
menentang pengklaiman oleh perusahaan yakni Bapak Arif, beliau mengatakan bahwa pada tahun 1988 seluruh berkas tanah seperti girik diambil oleh kelurahan dengan tujuan pemutihan dan masyarakat dibebaskan membayar IPEDA (Iuran Pembangunan Daerah), padahal sebelum adanya pemutihan masyarakat selalu membayar IPEDA setiap tahunnya. Pada tahun 1998 ada beberapa warga Jakarta yangmengaku kepemilikan atas tanah di Pulau Pari, kemudian saat Pantai Pasir Perawan yang ada di sebelah utara Pulau Pari menjadi obyek wisata yang berkembang pesat serta dapat meningkatkan roda perekonomian masyarakat, dari sinilah warga Jakarta yang mengaku kepemilikan tanah di Pulau Pari yang bersatu membentuk PT.Bumi Pari mulai memperjuangkan tanah yang ada di Pulau Pari. Berbeda dengan pendapat Bapak Arif, ternyata menurut salah satu warga yang pro terhadap PT. Bumi Pari, Bapak Hasan bahwa orang tuanya dulu tinggal di Pulau Tidung yang menjadi nelayan di Pulau pari, kemudian menetap di Pulau Pari dan tidak pernah membayar Iuran Pembangunan Daerah (IPEDA).

Konflik sengketa tanah di pulau pari ternyata menciptakan perpecahan antarmasyarakat, karena mereka yang pro selalu mendukung tindakan PT.Bumi Pari, berkebalikan dengan mereka yang kontra terhadap PT.Bumi Pari. Masyarakat yang pro adalah mereka yang sudah membangun komunikasi dengan PT. Bumi Pari yang dimandatkan oleh perusahaan untuk mengawasi dan melaporkan segala sesuatu yang terjadi di Pulau Pari, bisajuga disebut sebagai kaki tangan PT. Bumi Pari. Sedangkan masyarakat yang kontra adalah mereka yang ingin mempertahankan tanah yang dianggap hak mereka, karena pulau pari merupakan pusat perekonomian warga sekitar. Konflik pertanahan di Pulau Pari pun semakin tajam ketika terdapat beberapa pengawas yang dimandatkan oleh PT.Bumi Pari untuk mengawasi gerak gerik masyarakat Pulau Pari. Hal ini menimbulkan keresahan bagi masyarakat Pulau Pari, bukan hanya itu, ternyata beberapa pengawas tersebut merupakan warga Pulau Pari yang mendukung penuh PT. Bumi Pari. Kasus sengketa tanah yang menimbulkan perpecahan antar masyarakat Pulau Pari menarik perhatian penulis untuk menganalisis Persebaran Konflik Sengketa Tanah di Pulau Pari, Kepulauan Seribu, Jakarta.

\section{Kerangka Teori}

\section{Tinjauan Tentang Teori Representasi}

Representasi adalah sebuah sikap atau keadaan yang ditempatkan sebagai suatu perwakilan terhadap sebuah sikap atau perbuatan dari sekelompok orang/golongan tertentu di dalam sebuah lingkungan yang merupakan sebuah proses sosial yang berhubungan dengan pola hidup dan budaya masyarakat tertentu yang memungkinkan terjadi perubahan-perubahan konsep ideology dalam bentuk yang kongkrit (Hikmawan, 2017a). Representasi secara sederhana diartikan "menghadirkan yang tidak ada atau yang tidak hadir berubah untuk memahami praktek politik (Nuri Suseno). Representasi juga dipahami sebagai suatu perwakilan yang tidak harus dari election tetapi adanya self appointed representation yang berasal dari individu, kelompok masyarakat non pemerintah (Laura Montanaro dalam Nuri Suseno). Dalam hal ini, representasi perwakilan tidaklah selalu berpusat pada negara, perwakilan bisa terinstitusikan dalam media, gerakan sosial, tokoh 
masyarakat, LSM, partai dan akademisi (Tornquist dalam Suseno, 2013).

Perpolitikan di indonsesia sangat erat kaitannya dengan representasi politik karena representasi politik sering dipahami sebagai keterwakilan suatu pihak atas pihak lain. Representasi bukan hanya menyoal tentang pemilu tetapi juga masuk dalam ranah civil society (Toni, 2018). Sistem representasi yang ideal adalah representasi yang mampu menajmin terakomodasinya semua kelompok kepentingan, khususnya kelompok kepentingan yang termarjinalkan secara politik (misalnya elit local yang menguasai civil society) Menurut Michael Saward (dalam Nuri Sueno, 2013) secara umum seorang wakil dianggap sebagai seorang yang berdiri mengatasnamakan atau bertindak atas nama orang lain. Mereka melakukannya sebagai delegasi yang bertindak berdasarkan keinginan yang diekspresikan oleh pihak yang diwakili atau sebagai trustee (kepercayaan), yang bertindak berdasarkan kepentingan yang diwakilinya, inilah yang menjadi pondasi dari represetasi.

Dalam penelitian ini, penulis menggunakan konsep representasi menurut Hanna F Pitkin. Pitkin (1967) menjelaskan bahwa keterwakilan tidak harus berarti pemerintahan perwakilan. Seorang raja dapat mewakili sebuah bangsa, demikian juga seorang duta besar. Seorang pejabat publik dapat mewakili negara, dengan demikian institusi-institusi dan praktik-praktik yang merupakan perwujudan keterwakilan diperlukan di dalam sebuat masyarakat besar dan yang terartikulasian dan tidak harus terkait dengan pemerintahan untuk rakyat (Afala, 2017). Formulasi tentang representasi dan menyimpulkan bahwa perwakilan diri berarti tindakan untuk memenuhi kepentingan yang diwakili dalam upaya merespon kepentingan mereka (Cahasta, 2017). Perwakilan sifatnya haruslah independen, tindakannya haruslah melibatkan penilaian, dia harus menjadi satu-satunya yang bertindak yang diwakilinya pun juga harus mampu bertindak secara independen dan tidak hanya diam saja.

Pitkin (dalam Hawing dan Hikmawan) menjelaskan bahwa representasi dapat diidentikan dengan dua hal. Pertama, mengenai kewenangan (otoritas) dan yang kedua tanggung jawab. Kewenangan ini sering dikenal dengan sebuah pelimpahan keterwakilan satu pihak (individu atau kelompok) ke pihak lain. Dengan kata lain adalah pemberian otoritasnya atau kewenangannya (Hikmawan \& Hidayat, 2016). Pemberian otoritas ini kemudian yang menjadi dasar tindakan seperti apa yang harus dilakukan oleh pihak yang mewakili. Namun, karena otoritas ini merupakan hasil yang didapatkan dari orang lain, terdapat sebuah mekanisme yang harus dijalani, yaitu tanggung jawab kepada yang diwakili. Jadi dalam hal ini, harus mampu memaknai hal tersebut dengan suatu relasi dua arah yang terjalin di mana otoritas yang diberikan harus dibarengi dengan tanggung jawab kepada yang memberikan otoritas tersebut. Pitkin mencoba mendalami konsep representasi, di mana ia melihat bahwasanya social-system dari sebuah masyarakat pada faktanya memiki pola representasi yang beragam dan kompleks. Dari hal tersebut Pitkin belajar memetakan bagaimana pola-pola tersebut menjadi sebuah kategori yang dihasilkan dalam teori representasinya. Secara mendasar Pitkin (1967) ketika representator membawa kepentingan ide representasi ke dalam area kebijakan publik memberikan kategori representasi yang ideal ke dalam empat bentuk yang berbeda. Pertama, representasi otoritas/formalistic. Kedua, representasi deskriptif. Ketiga representasi simbolik dan yang keempat representasi substantive. Dari empat 
cara pandang tersebut, Pitkin membuat dua kategori yang menjadi pijakan dalam memahami model representasinya. Pertama stand for (berdiri sendiri), yaitu sebuah pola relasi yang terbangun karena pihak yang terbebani tanggung jawab. Kedua adalah act for (beraksi menggantikan) yaitu relasi yang terbangun karena ada pihak yang diberikan tanggung jawab. Kategori stand for terdiri dari representasi deskriptif dan representasi simbolik sedangkan kategori act for terdiri dari representasi formalistik/otoritasi dan representasi substansif. Pitkin kemudian menjabarkan keempat konsep representasi politik sebagai berikut :

\section{Representasi Otoritasi/Formalistik}

Perspektif otorisasi melihat bahwa representasi merupakan pemberian dan pemilikan kewenangan oleh wakil sebagai orang yang diberi kewenangan untuk bertindak. Wakil memiliki hak untuk bertindak, sesuatu yang tidak dimiliki sebelumnya. Sebaliknya, wakil yang memberikan beberapa haknya, harus ikut bertanggung jawab atas konsekuensi tindakan yang dilakukan oleh wakil. Pandangan otoritas ini memusatkan pada formalitas hubungan keduanya atau sering disebut sebagai pandangan fomalistik, oleh karenanya represntasi formal dipahami sebagai perwakilan politik yang berlangsung didalam lembaga-lembaga perwakilan formal. Contoh kepala negara mewakili rakyatnya dalam foum internasional. Dalam perspektif otoritas seorang wakil seolah-olah telah melakukannya sendiri, konsep ini sangat kuat dalam mendukung pewakilan, seorang wakil hanya melakukan apa yang diperintah oleh terwakil tanpa melakukan tindakan di luar perintah terwakil. Dalam memilih sorang wakil, terwakil harus mampu memilih seorang wakil yang sangat representatif, walaupun memberi otoritas kepada wakil, terwakil harus tetap mengontrol dan mengawasi segala yang dilakukan oleh wakil sehingga baik terwakil maupun yang mewakili memiliki hubungan saling mengikat.

\section{Representasi deskriptif}

Representasi deskriptif adalah seseorang dapat berpikir dalam kerangka sebagai standing for segala sesuatu yang tidak ada. Wakil bisa berdiri demi orang yang diwakili, menjadi substitusi untuk orang lain atau mereka cukup menyerupai orang lain. Representasi model ini dipahami sebagai kesamaan deskriptif antara wakil dengan yang diwakili. Cara pandangan ini kebanyakan dikembangkan diantara yang membela representasi proporsional yang berupaya menjamin bahwa badan perwakilan mencermnkan hitungan matematis "more or less" atas konstituennya. Proporsionalitas wakil ini terkait dengan komposisi komunitas, sebagai kondensasi dari keseluruhan.

\section{Representasi Simbolik}

Representasi simbolik berarti merepresentasikan sesuatu yang tidak dengan peta atau potret, tetapi dengan simbol, dengan disimbolkan atau diwakili secara simbolik. Meskipun sebuah simbol merepresentasikan "standing for" segala sesuatu, tetapi tidak menyerupai apa yang diwakili. Simbol memiliki ciri yang membantu merasionalisasi signifikansi simboliknya, sehingga simbol mensubstitusi yang diwakili dan simbol mensubstitusi apa yang disimbolkan. Model seperti ini merupakan bentuk representasi berdasarkan relasi simbolik yang ada di sosial 
kultural masyarakat dan adanya simbol tertentu yang menjadi system kepercayaan dan hadir dalam kehidupan masyarakat yang menjadi keseharian.

\section{Representasi Substantif}

Representasi substantif dalam konteks ini menyebutkan ketika representator membawa kepentingan ide-ide yang terepresentasi ke dalam area kebijakan public. Representasi substantif merupakan sebuah bentuk represntasi yang selalu mencari "isi" (substance) dari sebuah keterwakilan yang ada. Model ini memperlihatkan sesuatu yang menjadi tujuan bersama sehinggga tercapai semua kepentingan dari segala pihak. Representasi substantif lebih memusatkan pada hakekat aktifitas itu sendiri, dalam konteks ini wakil berbicara, bertindak demi opini, keinginan, kebutuhan atau kepentingan substantif terwakil. Konsep representatif memandang representasi bukan sekedar sebagai cara berdiri seseorang demi orang lain (a way of standing for someone) tetapi representasi sebagai cara bertindak demi orang lain ( $a$ way of acting for someone). Representasi substantif adalah bentuk representatif yang selalu mencari subtansi dari sebuah keterwakilan yang ada dan memperlihatkan sesuatu yang menjadi tujuan bersama, sehingga tercapai semua kepentingan dari segala aspek.

Dari keempat konsep representasi tersebut, representasi deskriptif maupun simbolik menjadi suplemen bagi pandangan yang formalistik. Representasi deskriptif memperkenalkan ide pentingnya wakil menyerupai konstituen. Sedangkan representasi simbolik masyarakat memiliki keyakinan irasional, yang diabaikan oleh pandangan formalistic. Representasi deskriptif dan simbolik biasanya dekat dengan objek (Pitkin, 1967).

\section{Metode Penelitian}

Metode penelitian yang digunakan adalah metode penelitian kualitatif. Bogdan dan Taylor (dalam Moleong,2006:4) mendefinisikan bahwa metodologi kualitatif sebagai prosedur penelitian yang menghasilkan data deskriptif berupa kata-kata tertulis atau lisan dari orang-orang dan prilaku yang dapat diamati. Pendekatan ini diarahkan pada latar dan individu tersebut secara holistic utuh (Hikmawan, 2014). Adapun, dalam penelitian ini pendekatan yang digunakan adalah pendekatan study kasus. Menurut Yin (dalam Creswell, 2014:135) penelitian study kasus mencakup study tentang suatu kasus dalam kehidupan nyata, dalam konteks atau setting kontemporer. Creswell (2014:135) melihat study kasus sebagai metodologi satu jenis desain dalam penelitian kualitatif yang dapat berupa objek penelitian dan juga hasil dari penelitian tersebut. Dalam penelitian ini, kasus yang dipilih adalah konflik sengketa tanah yang terjadi di Pulau Pari.

\section{Hasil dan Diskusi}

Konflik pertanahan yang terjadi di Pulau Pari sudah berlangsung selama bertahun-tahun, namun belum dapat diselesaikan sampai saat ini terlebih ketika ada 
beberapa aktor yang terlibat didalamnya. Bergitu pelik konflik yang terjadi di Pulau Pari akibat pengklaiman oleh perusahaan atas lahan di Pulau Pari, peneliti menggunakan teori Representasi yang merupakan sebuah sikap atau keadaan yang ditempatkan sebagai suatu perwakilan terhadap sebuah sikap atau perbuatan dari sekelompok orang/golongan tertentu di dalam sebuah lingkungan yang merupakan sebuah proses sosial yang berhubungan dengan pola hidup dan budaya masyarakat tertentu yang memungkinkan terjadi perubahan- perubahan konsep ideologi dalam bentuk yang kongkrit (Hikmawan, 2017b).

Teori representasi yang digunakan dalam penelitian ini adalah teori representasi dari Hanna F.Pitkin guna menjelaskan pola persebaran konflik yang terjadi di Pulau Pari karena konflik yang terjadi di Pulau Pari bukan hanya antara masyarakat dengan pihak swasta, tetapi antar masyarakat dengan masyarakat bahkan pejabat daerah terlibat didalamnya. Dalam konflik yang terjadi di Pulau Pari terlihat bahwa ada pihak-pihak yang merepresentasikan pihak lain dan ini merupakan pondasi dari sistem representasi seperti yang dijelaskan oleh Hanna F. Pitkin bahwa secara umum seorang wakil dianggap sebagai seorang yang berdiri mengatasnamakan atau bertindak atas nama orang lain. Mereka melakukannya berdasarkan keinginan yang diekspresikan oleh terwakil dan bertindak berdasarkan kepentingan terwakil, disamping itu pihak yang diwakili menaruh kepercayaan kepada wakilnya dan ini merupakan pondasi dari sebuah representasi. Pitkin menjelaskan 4 bentuk representasi yakni formalistic, deskriptif, simbolik, dan substantive.

\section{Posisi Pemerintah Daerah Sebagai Representasi Formalistik}

Konflik pertanahan yang terjadi di Pulau Pari telah melibatkan banyak pihak, konflik yang terjadi bukan hanya karena benturan kepentingan para pihak yang berkonflik, melaikan di picu oleh kebijakan negara yang belum sepenuhnya mengakomodir secara serius pengelolaan sumber daya alam.

Pemerintah Daerah yang merupakan pengayom masyarakat harus ikut serta dala m melerai konflik yang terjadi terlebih jika konflik tersebut menyangkut tanah yang notabene merupakan faktor utama keberlangsungan hidup manusia. Dalam konflik pertanahan yang terjadi di Pulau Pari, peneliti mengidentifikasi Pemerintah Daerah sebagai representasi formalistik/otorisasi karena perspektif otorisasi atau formalistik melihat bahwa representasi merupakan pemberian dan pemilikan kewenangan oleh wakil sebagai orang yang diberikewenangan untuk bertindak (Widiyanto, Hikmawan, \& Riswanda, 2019). Pandangan otoritas ini memusatkan pada formalitas hubungan, oleh karenanya representasi formal dipahami sebagai perwakilan politik yang berlangsung didalam lembaga-lembaga perwakilan formal (Pitkin, 1967). Beberapa aktor yang masuk dalam kategori representasi formalistik, terdiri dari, karena represntasi formal dipahami sebagai perwakilan politik yang berlangsung didalam lembaga-lembaga perwakilan formal (Pitkin, 1967) keduanya merupakan pejabat pemerintah daerah yang menjadi mediator dalam proses penyelesaian konflik yang ada di Pulau Pari. Mediasi yang dilakukan ditingkat kecamatan sebanyak 1 kali dan di kelurahan sebanyak 2 kali. Mediasi yang dilakukan adalah berupa perundingan guna mencapai kesepakatan yang menguntungkan kedua belah pihak, hal ini selaras dengan penjelasan terkait 
mediasi menurut Sujud Margono (2004) bahwa mediasi merupakan proses penyelesaian sengketa berdasarkan perundingan untuk membuat atau menghasilkan kesepakatan yang dapat diterima para pihak yang ditengahi oleh mediator yang bersikap netral dan terlibat langsung dalam perundingan.

Dalam proses mediasi, perwakilan dari pihak yang berkonflik selalu hadir namun tidak menemukan titik temu karena masing-masing yang berkonflik tetap pada pendiriannya. Masyarakat ingin mempertahankan tanah yang dianggap haknya dan tidak ingin bekerjasama dengan perusahaan sedangkan perusahaan terus ingin mewujudkan tujuannya.

\section{Gambar 1}

Sikap Pemerintah Daerah yang seharusnya

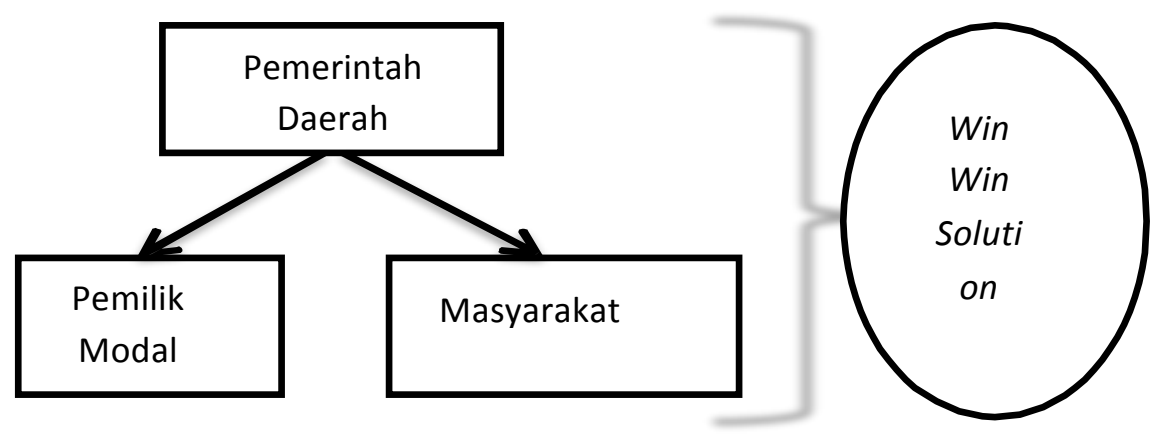

Sumber: peneliti

Gambar 2

Sikap Pemerintah Daerah (realita)
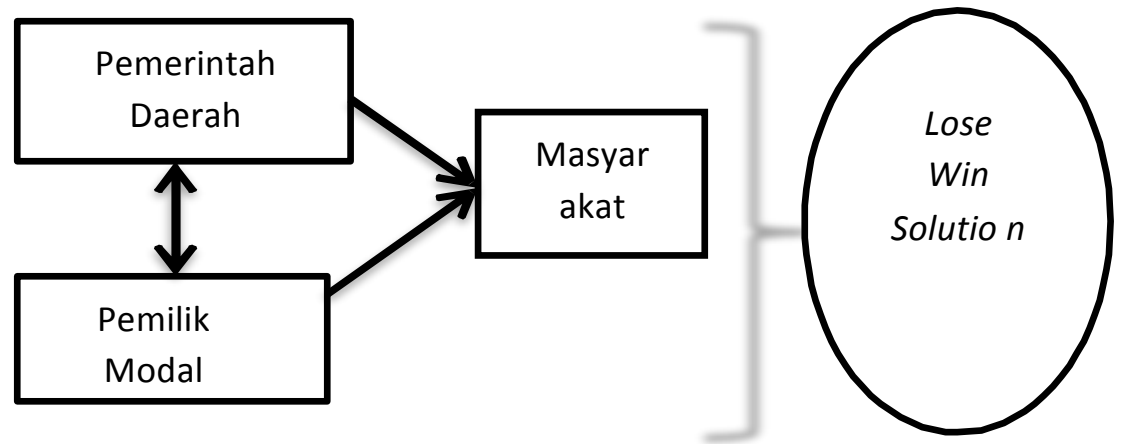

Sumber: peneliti

Sebagai mediator, pemerintah daerah seyogyanya bersikap netral dan harus memiliki solusi untuk para pihak yang berkonflik secara win win solution bukan lose win solution sebagaimana yang dijelaskan oleh Aria S. Hutagalung (2005) bahwa solusi yang dihasilkan dari proses mediasi mengarah kepada win win solution dan untuk mencapai win win solution ditentukan oleh proses pendekatan yang objektif terhadap sumber sengketa dan memberikan hasil yang saling menguntungkan 
dengan catatan bahwa pendekatan itu harus menitikberatkan pada kepentingan yang menajdi sumber konflik. Namun pada prakterknya, pemerintah daerah secara tidak langsung telah mendukung salah satu pihak dan menuntut masyarakat untuk tunduk pada keputusan yang diajukan oleh perusahaan.

Penolakan masyarakat atas keputusan perusahaan yang didukung oleh pemda bukan tanpa alasan, mereka menganggap bahwa bukti yang dimiliki perusahaan ilegal. Selain itu, masyarakat pun ingin objek wisata di Pulau Pari adalah objek wisata berbasis swadaya masyarakat tanpa campur tangan swasta. Sejalan dengan pendapat Bapak Arif, Asisten ORI menjelaskan bahwa sertifikat yang dimiliki perusahaan telah mengalami maladministrasi dan sekarang masih dalam proses tindak lanjut oleh lembaga ATR/BPN.Terlihat dari data yang di peroleh, pemerintah daerah lebih berpihak kepada pemilik modal. Pada proses mediasi, pemerintah daerah yang berperan sebagai mediator menuntut masyarakat untuk terus mengikuti keputusan tunggal yang dimiliki perusahaan dan pemerintah terkait pembagian sumber daya alam yang ada di Pulau Pari, hal ini tidak sejalan dengan prinsip mediasi yang dijelaskan oleh Aria S.Hutagalung (2005) bahwa mediasi memberikan para pihak perasaan kesamaan kedudukan dan upaya penentuan hasil akhir perundingan dicapai menurut kesepakatan bersama tanpa adanya paksaan dan tekanan. Tekanan dan paksaan inilah yang kemudian menjadi pemicu gagalnya proses mediasi yang selama ini sudah dilakukan. Keberpihakan pemerintah inilah yang kemudian menjadi faktor lain dari terjadinya konflik di Pulau Pari, sebagaimana dijelaskan oleh Maria Sumarjono (2009) bahwa konflik bukan hanya karena adanya kepentingan tetapi disebabkan oleh konflik struktural karena pola prilaku atau interaksi yang destruktif, pembagian sumber daya serta kewenangan yang tidak seimbang.

\section{Perlawanan Masyarakat Sebagai Representasi Simbolik}

Berdasarkan penelitian yang dilakukan, terdapat pihak yang dapat dikategorikan dalam representasi simbolik yakni pengelola objek wisata dan para pengusaha kecil di Pulau Pari yang merupakan perwakilan dari kelompok yang kontra terhadap perusahaan. Mereka dapat diidentifkasi ke dalam kategori representasi simbolik karena memiliki relasi simbolik yang merupakan bentuk dari kehidupan masyarakat dan menjadi budaya seperti yang dijelaskan Pitkin (1967) bahwa representasi simbolik merupakan bentuk representasi berdasarkan relasi simbolik yang ada di sosial kultural masyarakat dan adanya simbol tertentu yang menjadi sistem kepercayaan dan hadir dalam kehidupan masyarakat yang menjadi keseharian.

Dengan segala kekuasaan yang ada, pemerintah daerah dan perusahaan tidak segan-segan untuk menggunakan cara koersif agar masyarakat tunduk pada suatu kebijakan. Perlakuan yang demikian diinternalisasi oleh masyarakat dalam kesadaran sosial politiknya. Pada gilirannya, kesadaran yang bias state mengarahkan prilaku sosial masyarakat kepada hal yang bersifat diskriminatif. Ketika pemerintah mengalami defisit otoritas terlebih ketika munculnya reformasi telah menyediakan ruang yang lebih lebar kepada masyarakat terkait pendapatnya seperti adanya berbagai aksi yang melibatkan berbagai elemen yang dilakukan oleh masyarakat dalam melakukan perlawanan. Perlawanan yang dilakukan oleh masyarakat dari berbagai lini merupakan bentuk representasi karena representasi tidaklah selalu 
berpusat pada negara, perwakilan bisa terinstitusikan dalam media, gerakan sosial, tokoh masyarakat, LSM, partai dan akademisi (Tornquist dalam Suseno, 2013). Bukan hanya itu, Olle Tornquist pun memandang bahwa dalam representasi simbolik pihak yang mewakili merasa mewakili karena kesamaan budaya dan identitas. Dalam hal ini terlihat jelas bahwa mereka yang kontra terhadap perusahaan termasuk dalam kategori representasi simbolik dan merupakan bentuk perwakilan yang memperlihatkan bahwa mereka memiliki kesamaan identitas seperti yang dipaparkan oleh A.H Birch (dalam Adrianus,dkk,2006) bahwa representesi simbolik adalah mereka mewakili kelompok tertentu yang melambangkan identitas atau kualitas golongan yang diwakilinya.

Bentuk perlawanan yang dilakukan masyarakat kontra tidak terlepas dari apa yang melatarbelakanginya, dalam hal ini faktor utama penyebab konflik yang terjadi di Pulau Pari adalah karena adanya persaingan kepentingan yang terkait dengan kepentingan substantive seperti sumber daya agrarian termasuk tanah (Maria Sumarjono, 2009), adanya persaingan kepentingan dapat dilihat dari perebutan sumber daya antara msyarakat dengan perusahaan terlebih ketika ada beberapa masyarakat yang mendukung perusahaan, hal ini yang membuat masyarakat terpecah menjadi 2 kubu.

Masyarakat yang menentang perusahaan menginginkan wisata di Pulau Pari dikelola secara swadaya tanpa campur tangan investor, terlebih ketika tuduhan masyarakat atas sertifikat illegal yang dimiliki perusahaan benar adanya. Sedangkan masyarakat yang pro terhadap perusahaan selalu mendukung perusahaan dengan tujuan ikut serta mengelola wisata di Pulau Pari dan membangun resort. Objek wisata di Pulau Pari merupakan hasil swadaya masyarakat, dari pengembangan objek wisata inilah yang membuat perekonomian masyarakat sangat terjamin, terlihat dari usaha-usaha masyarakat seperti penyewaan homestay, usaha catering, warung-warung sekitar pantai, penyewaan alatalat snorking, dan lain- lain. Hal inilah yang membuat masyarakat menolak kedatangan perusahaan.

Di Pulau Pari terdapat 3 objek wisata andalan yakni Pantai Pasir Perawan, Pantai Kresek dan Pantai Bintang. Perusahaan telah melakukan komunikasi dengan setiap pengelola objek wisata dengan tujuan mengajak kerjasama dalam pengelolaan objek wisata, namun hanya pengelola pantai kresek yang menerima kerjasama dengan perusahaan dan kerjasama tersebut hanya berjalan beberapa bulan sehingga saat ini pantai kresek tidak dijadikan objek wisata karena terdapat konflik internal diantara pengelola.

Masyarakat yang kontra terhadap perusahaan awalnya tidak melakukan perlawanan atas pengklaiman dari pihak perusahaan. Namun setelah perusahaan melakukan tindakan yang meresahkan warga Pulau Pari dengan menugaskan security disetiap titik Pulau Pari bahkan mempidanakan salah satu warga Pulau Pari yang dianggap melakukan penyerobotan tanah maka warga Pulau Pari mulai melawan, Perlawanan yang dilakukan masyarakat yang kontra dengan menolak kedatangan perusahaan dan melakukan aksi berkali-kali dari mulai tingkat kelurahan sampai dengan tingkat propinsi guna menuntut keadilan tidak terlepas dari dukungan beberapa LSM, seperti WALHI (Wahana Lingkungan Hidup Indonesia), IFC (Indonesia Fight Corporation) dan FPPP (Forum Peduli Pulau Pari). 
Volume 1 Issue 3, Month Year

http://hk-publishing.id/ijd-demos

\section{Masyarakat Pro Sebagai Representasi Deskriptif}

Menurut Pitkin (1967) representasi deskriptif adalah seseorang dapat berpikir dalam kerangka sebagai standing for segala sesuatu yang tidak ada. Wakil bisa berdiri demi orang yang diwakili, menjadi substitusi untuk orang lain atau mereka cukup menyerupai orang lain. Cara pandangan ini kebanyakan dikembangkan diantara yang membela representasi proporsional yang berupaya menjamin bahwa badan perwakilan mencermnkan hitungan matematis "more or less" atas konstituennya. Proporsionalitas wakil ini terkait dengan komposisi komunitas, sebagai kondensasi dari keseluruhan.

Dalam penelitian ini, peneliti mengidentifikasi pihak yang pro terhadap perusahaan termasuk ke dalam representasi deskriptif. Dikatakan sebagai representasi deskriptif karena prinsip dari reprsentasi deskriptif adalah wakil bisa berdiri demi orang yang diwakili, menjadi substitusi untuk orang lain atau mereka cukup menyerupai orang lain (Pitkin, 1967), pandangan ini mendapat dukungan dari Olle Tornquist (dalam Suseno,2013) yang mengatakan bahwa representasi deskripif adalah ketika wakil mewakili secara serupa dengan yang diwakili, dalam hal ini wakil bepihak pada yang diwakili dan pihak yang pro terhadap perusahaan merupakan representasi perusahaan yang langsung ada di lapangan karena representasi secara sederhana diartikan "menghadirkan yang tidak ada atau yang tidak hadir berubah untuk memahami praktek politik" (Nuri Suseno).

Dalam konsep perwakilan, secara umum seorang wakil dianggap sebagai seseorang yang berdiri mengatasnamakan atau bertindak atas nama orang lain (yang tidak hadir). Mereka melakukannya sebagai delegasi yang bertindak berdasarkan keinginan yang diekspresikan oleh pihak yang diwakili atau sebagai trustee (kepercayaan), yang bertindak berdasarkan kepentingan yang diwakilinya, inilah yang menjadi pondasi dari represetasi (Michael Saward). Dalam hal ini masyarakat yang pro terhadap perusahaan merupakan jembatan informasi antara perusahaan dengan masyarakat yang kontra karena pihak perusahaan tidak menetap di Pulau Pari sehingga perusahaan membutuhkan orang-orang yang menetap di Pulau Pari yang dapat dijadikan sebagai kaki tangan atau trustee (kepercayaan) perusahaan dan mereka selalu melakukan tindakan sesuai apa yang diinginkan perusahaan dan mereka selalu mendukung penuh tindakan perusahaan.

Pihak yang pro terhadap perusahaan sangat jauh berbeda jumlahnya jika dibandingkan dengan pihak yang kontra, hal inilah yang menyebabkan terkucilkannya pihak yang pro. Masyarakat Pulau Pari awalnya tidak terbagi menjadi 2 kubu, yang pro terhadap perusahaan awalnya tidak mendukung perusahaan, mereka pun takut usaha yang dimilikinya akan dikuasai karena mereka merupakan orang-orang yang sudah punya usaha yang cukup besar di Pulau Pari. Namun kemudian mereka mendukung perusahaan dengan alasan taat aturan.

Perubahan sikap yang dilakukan oleh pihak yang pro yang awalnya diam namun kemudian mendukung penuh perusahaan terlebih mereka memiliki banyak usaha di Pulau Pari, ini menunjukan bahwa adanya komunikasi politik yang sudah dilakukan oleh pemilik modal dengan pihak yang pro. Keduanya memiliki kepentingan, terbukti dari tindakan perusahaan yang mempekerjakan masyarakat yang pro sebagai pegawai perusahaan. Perubahan sikap masyarakat yang awalnya diam namun kemudian menjadi pihak yang pro terhadap perusahaan menimbulkan emosi yang berlebihan yang ada pada masyarakat kontra, tidak hanya itu, hal ini 
pun berpengaruh pada prilaku masyarakat yang cenderung negative.

Dari data yang di dapat terlihat bahwa selain konflik kepentingan dan konflik struktural, konflik yang terjadi di Pulau Pari pun disebabkan oleh konflik hubungan karena emosi yang berlebihan, persepsi yang keliru, komunikasi yang buruk atau salah, menggunakan prilaku yang negatif (Maria Sumardjono, 2009). Dari konflik antara masyarakat dengan perusahaan dan masyarakat dengan masyarakat yang terjadi di Pulau Pari terlihat jelas bahwa pola interaksi atau hubungan antara pihak yang berkonflik sangat buruk, hal inilah yang menjadi salah satu faktor konflik di Pulau Pari terus terjaga.

\section{Ombudsman RI Sebagai Representasi Substantif}

Peneliti melihat bahwa dalam konflik pertanahan yang terjadi di Pulau Pari, Ombudsman RI yang merupakan lembaga formal masuk dalam ranah representasi substantif, dimana representasi substantif merupakan sebuah bentuk representasi yang selalu mencari "isi" (substance) dan membawa kepentingan yang terepresentasi ke dalam area kebijakan publik (Pitkin, 1967). Selain Pitkin, Olle Tornquist (dalam Faisal Aminudin, 2012) memandang bahwa representasi substantif seperti halnya ketika DPR/DPRD yang merupakan suatu lembaga mewakili kelompok buruh kemudian membela kepentingan buruh. Selaras dengan pandangan tersebut terlihat jelas bahwa Ombudsman yang merupakan lembaga Negara (formal) dapat dikategorikan sebagai representasi substantif karena Ombudsman RI telah memperjuangkan kepetingan dan aspirasi rakyat walaupun belum dapat melerai konflik secara keseluruhan tapi setidaknya Ombudsman benar-benar telah membawa kepentingan dari masyarakat melalui sikapnya terhadap konflik pertanahan di Pulau Pari yang menunjukan perlawanan atas tindakan salah yang dilakukan oleh BPN atas penerbitan sertifikat lahan di Pulau Pari. Dalam gerakannya, peneliti melihat bahwa Ombudsman merupakan lembaga negara yang melakukan politik transformatif yang disandarkan pada nilai-nilai kebebasan dan keadilan sehingga tercipta win win solution serta kedamaian.Masyarakat melaporkan kasus ini kepada Ombudsman Republik Indonesia (ORI) dengan tujuan ORI dapat bersikap netral karena masyarakat merasa tidak ada yang melindunginya termasuk pemerintah daerah.

Selaras dengan penjelasan Bapak Arif, salah satu Asisten. Ombudsman yang menangani kasus di Pulau Pari pun menjelaskan bahwa sertifikat yang dimiliki perusahaan mengalami maladministrasi. Dari kasus yang terjadi di Pulau Pari, Ombudsman RI merupakan lembaga negara yang menginginkan pemerintah daerah termasuk BPN memperhatikan kepentingan- kepentingan dari masing-masing pihak yang berkonflik bukan hanya kepentingan dari salah satu pihak, hal ini menjadi penunjang bahwa Ombudsman RI teridentifikasi ke dalam representasi substantive seperti yang dijelaskan Pitkin (1967) bahwa model representasi substatif memperlihatkan sesuatu yang menjadi tujuan bersama sehinggga tercapai semua kepentingan dari segala pihak. Adanya keputusan yang Setelah dikeluarkannya LAHP (Laporan Akhir Hasil Pemeriksaan) oleh ORI yang menunjukan adanya maladministrasi dalam penerbitan sertifikat, BPN Pusat dan pejabat daerah masih dalam proses penyelidikan tindak lanjut atas penerbitan sertifikat yang dilakukan 
oleh BPN Jakarta Utara.

\section{Kesimpulan}

Berdasarkan uraianyang telah disampaikan pada bab sebelumnya pola persebaran konflik pertanahan yang terjadi di Pulau Pari pada dasarnya disebabkan oleh konflik struktural, konflik kepentingan dan konflik hubungan yang berwujud pada konflik vertikal maupun horizontal. Dalam konflik pertanahan yag terjadi di Pulau Pari terlihat bagaimana perusahaan dan pemerintah daerah memberikan tekanan kepada masyarakat agar tunduk padanya, namun ternyata masyarakat yang di sokong oleh LSM melakukan perlawanan untuk menelitik keabsahan sertifikat yang dimiliki perusahan. Secara praktis, gerakan perlawanan yang dilakukan oleh masyarakat kontra ini merupakan wujud nyata yang menunjukan bahwa dewasa ini masyarakat harus bersikap kritis sehingga tidak mudah dibodohi oleh elit penguasa. Disisi lain, perusahaan yang merupakan pemilik modal terus aktif melebarkan sayapnya salah satunya dengan menjadikan masyarakat yang pro terhadapnya sebagai kaki tangan perusahaan, bukan hanya itu, pemerintah daerah yang seharusnya netral namun pada prakteknya telah berpihak pada pemilik modal dan menjadikan konflik semakin pelik. Konflik pertanahan yang terjadi di Pulau Pari telah banyak melibatkan beberapa aktor sehingga pola persebaran konflik teridentifikasi ke dalam beberapa bentuk representasi diantaraya Pemerintah Daerah sebagai representasi formal, masyarakat yang kontra sebagai representasi simbolik, masyarakat yang pro sebagai representasi deskriptif dan Ombudsman sebagai representasi substantif.

Dalam penelitian ini ditemukan bahwa ORI yang merupakan lembaga formal ternyata masuk dalam ranah representasi substantif, karena hasil penelitian menunjukan bahwa Ombudsman RI telah memperjuangkan kepetingan dan aspirasi rakyat walaupun belum dapat menyelesaikan konflik secara keseluruhan tapi setidaknya Ombudsman benar-benar telah membawa kepentingan dari masyarakat melalui sikapnya terhadap konflik pertanahan di Pulau Pari yang menunjukan perlawanan atas tindakan salah yang dilakukan oleh BPN atas penerbitan sertifikat yang dinilai telah mengalami maladministrasi. Di lihat dari pergerakan yang dilakukan oleh Ombudsman sebagai lembaga formal, teori Pitkin yang menjelaskan bahwa lembaga formal termasuk dalam kategori representasi formalistik ternyata bisa masuk dalam kategori representasi substantif.

\section{Referensi}

Afala, L. M. (2017). Menalar Dinamika Konflik Wisata Goa Pindul. Journal of Governance, 2(1). https://doi.org/10.31506/jog.v2i1.2121

Agustino Leo. 2004. Konflik dan Pembangunan Politik Vol.22, No.3 (www.academia.edu) diakses 2/04/2018

Aminudin Faisal, Efektifitas Keterwakilan Politik : Revitalisasai Fungsi Parpol dan Kompetisi Kandidat pada Sistem Daftar Terbuka, Jurnal Ilmu Politik AIPI, No.22 tahun 2012

Cahasta, L. A. (2017). Journal of Governance, Desember 2017 Volume 2, no. 2 248, 
Volume 1 Issue 3, Month Year

http://hk-publishing.id/ijd-demos

2(2), 248-276. https:// doi.org/http:/ / dx.doi.org/10.31506/jog.v2i2.2679

Creswell, John.W. 2014. "Penelitian Kualitatif \& Desain Riset". Yogyakarta:Pustaka Pelajar

Fisher, Simon, dkk. 2001. "Mengelola Konflik, Keterampilan dan Strategi Untuk Bertindak". Jakarta: The British Council.

Hawing,Hardianto dan Hikmawan, Dian M. Menguji Perspektif Teori Representasi : Telusur Konsep Dan Praktik Konflik Di Tempat Wisata Goa Pindul (www.academia.edu) diakses 20/03/2018

Hikmawan, M. D. (2014). Politik Perbedaan : Demokrasi dalam Paradoks. Universitas Gdjah Mada.

Hikmawan, M. D. (2017a). Pluralisme Demokrasi Politik di Indonesia. Journal of Governance, 2(2), 223-247.

https://doi.org/http://dx.doi.org/10.31506/jog.v2i2.2678

Hikmawan, M. D. (2017b). Politik Perbedaan: Minnoritas dalam Implementasi

Kebijakan. Journal of Indonesian Public Administration and Governance Studies (JIPAGS), 1(1), 88-98.

Hikmawan, M. D., \& Hidayat, R. (2016). Depoliticisation of Public Issue : Low

Degree of Government ' S Democratic Legitimacy. Journal of Governance, 1(1),

23-37. https:/ / doi.org/http:/ / dx.doi.org/10.31506/jog.v1i1.1311

Liandra Pati Rangga. 2012. Manajemen Konflik Agraria Studi Kasus Desa Tangun Kecamatan Bangun Purba Kabupaten Rokan Hulu. di akses 9/02/2018

Maria S.W, Sumardjono. 2009. “Tanah Dalam Perspektif Hak Ekonomi, SosialEBudaya”. Jakarta:Kompas

Moleong, Lexyj. 2006. "Metodologi Penelitian Kualitatif" edisi revisi. Bandung: Remaja Rosdakarya

Morisan. 2012. "Metode Penelitian Survey" Edisi 1. Jakarta: Kencana Prenada Media Group

Mulyadi. 2007. Social Conflicts Evaluated From The Angle Of Structure and Function (http:Jurnal-humaniora.ugm.ac.id) diakses 19/03/2018

Nasution.2003. “Metode Penelitian Naturalistik Kualitatif”. Bandung: PT.Tarsito

Pandaleke, Alfien. 2015. The Effect Of Social Conflict On The Enviromental Security Disruption Of Coastal Communities in the Bitung City Indonesia. Vol.49 No.4

Pitkin, Hanna F. 1967. "The Concept of Representation". Barkeley : University of California Press

Sugyono. 2012. “Metode Penelitian Kuantitatif, Kualitatif, dan RED”. Bandung:Alfabeta

Sugyono. 2016. “Metode Penelitian Kuantitatif, Kualitatif, dan RED”. Bandung:Alfabeta

Suseno, Nuri, 2013, Representasi Politik : Perkembangan dari Ajektiva ke Teori, PUSKAPOL FISIP UI, 2013

Toni, H. (2018). Potret Representasi Pengelolaan Goa Pindul (Studi Representasi 
Volume 1 Issue 3, Month Year

http:/ / hk-publishing.id/ijd-demos

Pokdawis Karya Wisata Tahun 2014). Journal of Governance, 3(1), 67-79. https://doi.org/10.31506/jog.v3i1.3008

Widiyanto, A., Hikmawan, M. D., \& Riswanda, riswanda. (2019). JSPG: Journal of Social Politics and Governance Implementasi Rencana Aksi Nasional Bela Negara Berdasarkan Instruksi Presiden Nomor 7 Tahun 2018 Oleh Dewan Ketahanan Nasional Republik Indonesia. Journal of Social Politics and Governance, 1(2), 95-115.

Wijono, Sutarto. 2012. "Psikologi Industri dan Organisasi”. Jakarta:Kencana

Winardi. 1994. Manajemen Konflik : Konflik Perubahan dan Pengembangan. Bandung : Mandar Maju

Winarta, H.Frans. 2012. “Hukum Penyelesaian Sengketa”. Jakarta:Sinar Grafika 